\title{
イットリア添加正方晶ジルコニア（Y-TZP）の熱疲労
}

\author{
芦塚正博 - 藤井秀樹・木村泰之・窪田吉孝* \\ $\left(\begin{array}{c}\text { 九州工業大学 金属加工学科 } \\ \text { *東洋曹達工業 }(\text { 株) }\end{array}\right.$
}

\section{Thermal Fatigue Behavior of $\mathrm{Y}_{2} \mathrm{O}_{3}$-Containing Tetragonal Zirconia Polycrystals (Y-TZP)}

\author{
Masahiro ASHIZUKA, Hideki FUJII, Yasuyuki KIMURA \\ and Yoshitaka KUBOTA* \\ Kyushu Institute of Technology \\ 1-1, Sensui-cho, Tobata-ku, Kitakyushu-shi 804 \\ * Toyo Soda Manufacturing Co., Ltd.
}

\begin{abstract}
The theremal fatigue behavior of 3 mol\% $Y_{2} \mathrm{O}_{3}$-containing tetragonal zirconia polycrystals ( $Y$-TZP) with average grain sizes of $0.4 \mu \mathrm{m}(Z 3 Y-I)$ and $1.0 \mu \mathrm{m}(Z 3 Y-I I)$ was studied by quenching into water bath at $20^{\circ} \mathrm{C}$. The retained strength distribution of Z3Y-I subjected to multiple cycle quench at $\Delta T=350^{\circ}$ and $300^{\circ} \mathrm{C}$ showed a shoulder at a certain $\mathrm{F}$ level, which corresponds to the initiation point of thermal shock damage. The $F$ level increased with increasing thermal shock cycle number. For Z3Y-I at $\Delta T=350^{\circ}$, the proportion of damaged specimens was half for 1 cycle quenching and most for 10 cycles. At $\Delta T=300^{\circ} \mathrm{C}$, the proportion of damaged specimens was none for 1 cycle, a few for 8 cycles and half for 60 cycles, but at $250^{\circ} \mathrm{C}$, no crack was generated at 90 thermal shock cycles. On the other hdnd, the strength distribution of $Z 3 Y-I I$ subjected to multiple cycle quench at $350^{\circ} \mathrm{C}$ was similar to that of $Z 3 Y-I$ at $\Delta T=350^{\circ} \mathrm{C}$, but those of Z3Y-II at $\Delta T=300^{\circ}$ and $250^{\circ} \mathrm{C}$ were followed by decreasing standard deviation, and the difference between maximum and minimum strengths was within about $3.1 \%$ for the thermal shock cycles above fifteen. The average strength of Z3Y-II subjected to 75 thermal shock cycles at $\Delta T=300^{\circ} \mathrm{C}$ and 90 cycles at $\Delta T=250^{\circ} \mathrm{C}$ were about 60 and $76 \%$ of the original strength before water quench, respectively. The thickness of zone transformed from tetragonal to monoclinic phase by chemical reaction with hot water was $103 \mu \mathrm{m}$ for 30 thermal shock cycles, $155 \mu \mathrm{m}$ for 50 cycles and $356 \mu \mathrm{m}$ for 75 cycles at $\Delta T=300^{\circ} \mathrm{C}$, and 36 $\mu \mathrm{m}$ for 60 cycles and $211 \mu \mathrm{m}$ for 90 cycles at $\Delta T=250^{\circ} \mathrm{C}$.

[Received February 19, 1986]
\end{abstract}

Key-words : Partially stabilized zirconia, Tetragonal zirconia polycrystals, Zirconia, Thermal fatigue, Thermal shock damage, Weibull distribution function, Doubly exponential distribution function

\section{1. 緒 言}

近年，高強度・高靶性セラミックスの開発が進み，そ の耐熱性, 耐摩耗性及び耐食性等の特長を生かした各種 機械装置用構造材料としての利用が検討され，一部は実 用化されている。このような方面への利用に際してはセ ラミックスの耐熱衝撃特性が重要因子になるため，それ に関する多くの研究が発表されている(1) 11)。しかし，そ れらの研究の大部分は 1 回の急冷によりき裂が発生し強 度低下を起こす臨界温度差 $\Delta T_{\mathrm{c}}$ に関するものである。 著者ら $^{11)}$ もイットリア添加正方晶ジルコニア (Y-TZP) の熱衝撃破壊挙動を研究し，セラミックスの熱衝撃破壊 は平均的に進行するのでなく，一定の強度分布，すなわ ち，き裂の大きさの分布をもった試料のなかで熱応力 $\sigma_{\mathrm{t}}$ と潜在き裂の大きさ $c$ の関係が破壊鞁性 $K_{\mathrm{IC}}$ と一定 の関係に達したものから順次き裂の伸長が生じ破壊して いくことを明らかにした。更に，き裂発生の際の応力拡 大係数 $K_{\mathrm{I}}$ は臨界応力拡大係数 $K_{\mathrm{IC}}$ にまで達していない
ことを示し，その原因として slow crack growth の関与 した疲労と熱水との化学反応による正方晶から単斜晶へ の相変態の関与による劣化が重畳している可能性もある ことを示唆した。

セラミックスを高温部材として利用する場合, 繰り返 し急熱急冷条件下で使用される可能性も多いため臨界温 度差 $\Delta T_{\mathrm{c}}$ に関するのみならず，臨界温度差 $\Delta T_{\mathrm{c}}$ 以下の 温度での繰り返し急熱急冷による強度劣化, すなわち, 熱疲労に関する特性も把握しておくことが重要である.

セラミックスの熱疲労に関する研究としては Hasselman のグループ12) 14),18), Ammann ら ${ }^{15)}$, Kamiya と Kamigaito $^{16), 17)}$ ， Lamon ${ }^{19)}$ 及び Lewis と Rice ${ }^{20)}$ による 研究がある程度で，他の熱的・機械的特性に比べ非常に 少ない。

本研究では高強度・高勒性材料として注目されている イットリア添加正方晶ジルコニアの熱疲労を繰り返し水 中急冷法で測定した。 


\section{2. 実験方法}

実験に使用した試料は $3 \mathrm{~mol} \% \mathrm{Y}_{2} \mathrm{O}_{3}$ を含んだジルコ ニア粉末を金型を使って $20 \mathrm{MPa}$ の圧力で予備成形し, 更にラバープレスを使って $300 \mathrm{MPa}$ の圧力で本成形し たあと大気中 $1450^{\circ}$ 及び $1600^{\circ} \mathrm{C} て ゙ 2$ 時間焼成したもの である(東洋曹達工業製)。 $1450^{\circ} \mathrm{C}$ 焼成体 (Z 3 Y - I と 略す) は平均粒径が $0.4 \mu \mathrm{m}, 1600^{\circ} \mathrm{C}$ 焼成体 (Z 3 Y-II と略す）は平均粒径が $1 \mu \mathrm{m}$ である. 試験片寸法は $3 \times 3$ ×45 mm で表面研削は長さ方向へ\#200のダイヤモン ド砥石で行った。

臨界温度差 $\Delta T_{\mathrm{c}}$ 近傍の温度差である $\Delta T=350^{\circ} \mathrm{C}$ で の急冷には 20 個の試料を， $300^{\circ}$ 及び $250^{\circ} \mathrm{C}$ では 8 個の 試料を 1 組として所定の温度に加熱後, $20^{\circ} \mathrm{C}$ の水中へ 投入し急冷した。それらを乾燥後, 再度炉中へ入れ所定 の温度に 30 分保持した後，水中急冷することを繰り返 した。

強度は下部スパン $30 \mathrm{~mm}$, 上部スパン $10 \mathrm{~mm} の 4$ 点 曲げで測定した.クロスヘッドスピードは $0.5 \mathrm{~mm} / \mathrm{min}$ である。

\section{3. 実験結果}

セラミックスの強度分布を整理する場合, ワイブル分 布関数を利用することが多い。しかしワイブル分布関数 では，例えば $50 \mathrm{MPa}$ から $80 \mathrm{MPa}$ の間の強度変化は $500 \mathrm{MPa}$ から $800 \mathrm{MPa}$ の間の強度変化と同じ程度に強

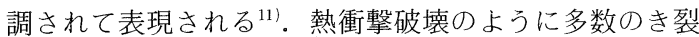
が入ったため強度が低下し 50 〜 $80 \mathrm{MPa}$ と小さくなっ た材料の強度測定では, 試料内でのき裂の位置, 方向等 により測定強度は微妙に変化するため，それらをプロッ トしたグラフでは，その変化の傾向が実体以上に強調さ

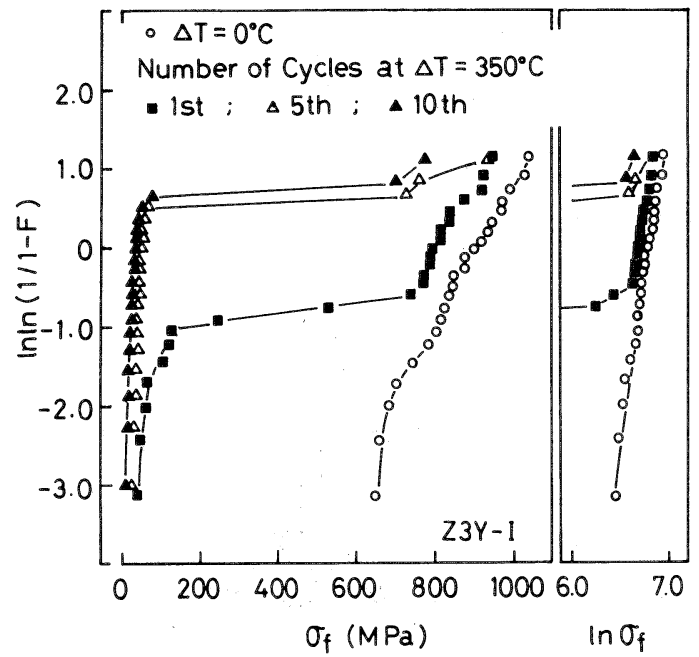

Fig. 1. Retained strength of multiple cycle thermal shocked specimens $(Z 3 \mathrm{Y}-\mathrm{I})$ for $\Delta T=350^{\circ} \mathrm{C}$ shown using the Weibull distribution function and the doubly exponential distribution function.
れすぎる傾向があった ${ }^{11)}$.これらのことより, 前報と同 様に，データの表示は全体の変化を二重指数分布関数で 整理して示し, 高強度側のみをワイブル分布関数で整理 し，両方を併用して熱疲労を考察することにする。

(1) $\Delta T=350^{\circ} \mathrm{C}$

前報 ${ }^{11)}$ では，Z 3 Y-I 及び Z 3 Y- II の臨界温度差 $\Delta T_{\mathrm{c}}$ は $350^{\circ} \mathrm{C}$ 近傍にあることを示し, この温度で急冷 した後の強度分布の傾向より, 低強度側の約半数の試料 はき裂が入り強度が大きく低下するが，高強度側の残り 半数の試料は急冷する前のき裂分布と類似していること を明らかにした。図 1 及び図 2 中の繰り返し回数 1 回の デー夕は前報の結果である。このような試料について急 冷を更に 5 回, 10 回と繰り返した場合の強度分布も図 1 及び図 2 に示した。全体的な傾向はZ 3 Y - I とZ 3 Y-II では類似していた。1 回の急冷では急冷する前の

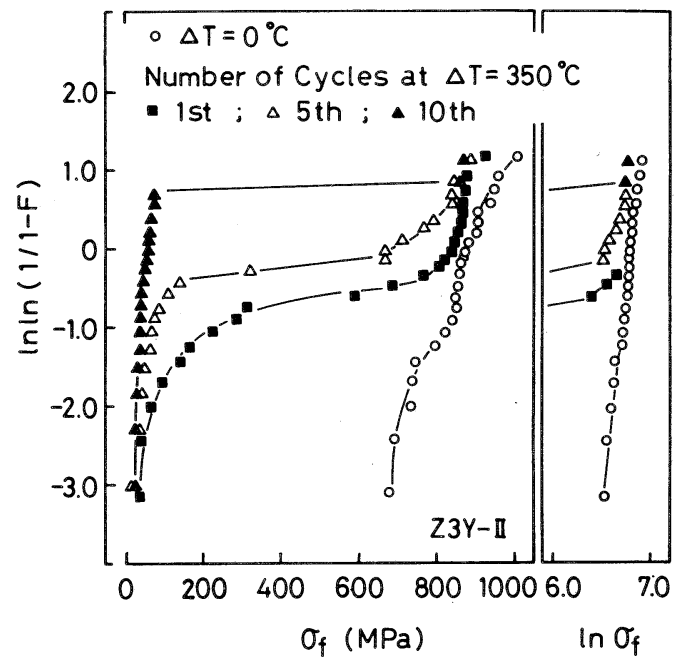

Fig. 2. Retained strength of multiple cycle thermal shocked specimens $(Z 3 \mathrm{Y}-\mathrm{II})$ for $\Delta T=350^{\circ} \mathrm{C}$ shown using the Weibull distribution function and the doubly exponential distribution function.

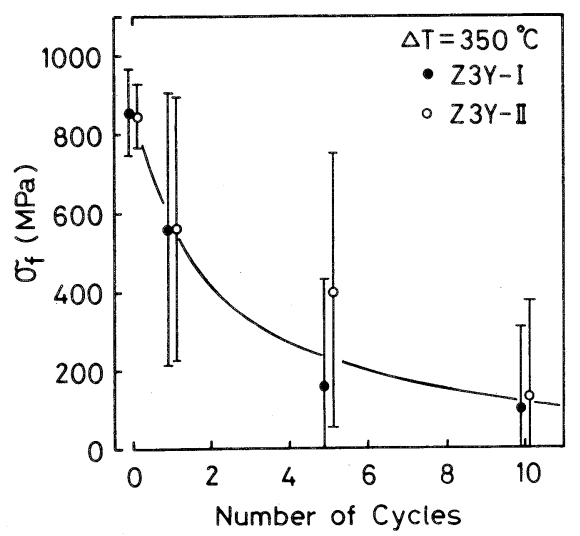

Fig. 3. Variation of average retained strength of $Z 3 Y$ $\mathrm{I}$ and $\mathrm{Z} 3 \mathrm{Y}-\mathrm{II}$ with the number of thermal shock cycles. Error bars are \pm 1 standard deviation. 
き裂分布と類似した強度分布を示した高強度側の半数の 試料も 5 回, 10 回と急冷を繰り返していくにつれき裂 が発生する試料の数は増大する. 図 1 及び図 2 のワイブ ル分布関数での整理の部分から明らかなように，10回 の急冷を行った後でも高強度側の $2 \sim 3$ 個の試料は急冷 する前の強度分布に近い高い值を維持していた．図 3 は 急冷温度差 $\Delta T$ が $350^{\circ} \mathrm{C}$ の場合の急冷回数亡平均強度 の関係である. 平均強度は急冷回数の増加とともに減少 しているが，標準偏差も大きく，平均強度から熱疲労機 構を明らかにするのは非常に因難であると考えられる.

\section{(2) $\Delta T=300^{\circ} \mathrm{C}$}

$\Delta T=300^{\circ} \mathrm{C}$ での Z 3 Y - I の結果を図 4 及び図 5 に, Z 3 Y-II の結果を図 6 及び図 7 に示す. 図 4 と図 6 の 比較から明らかなようにZ $3 \mathrm{Y} \cdot \mathrm{I}$ とZ $3 \mathrm{Y}$-II とでは残 存強度分布に大きな差異が認められる.Z 3 Y - I の場合, 1 回程度の急冷ではき裂が発生しないが，急冷を繰り返 し 8 回になると低強度側の一部の試料にき裂が入り強度 は低下する. 急冷回数が増加し 60 回になると低強度側 の半数近くの試料にき裂が入った。しかし，高強度側の 残り半数の試料は急冷する前の試料の強度分布之類似し た傾向を示した．繰り返し回数の増加とともに残存強度 分布が変化していく様子は図 1 及び図 2 に示した $\Delta T=$ $350^{\circ} \mathrm{C}$ の場合之類似していた.

図 5 は縦軸に残存強度を, 横軸に繰り返し急冷回数を とって全測定点をプロットしたものである．データにか なりのばらつきがあり，繰り返し急冷回数も 60 回以下 と少ないため詳細な考察は難かしいが, 定性的には繰り 返し回数が増すとき裂が入り強度が低下する試料の数は 増大する傾向にある．き裂が入っていない高強度側の試 料に注目してみると，大部分の測定点は破線 A, B の間

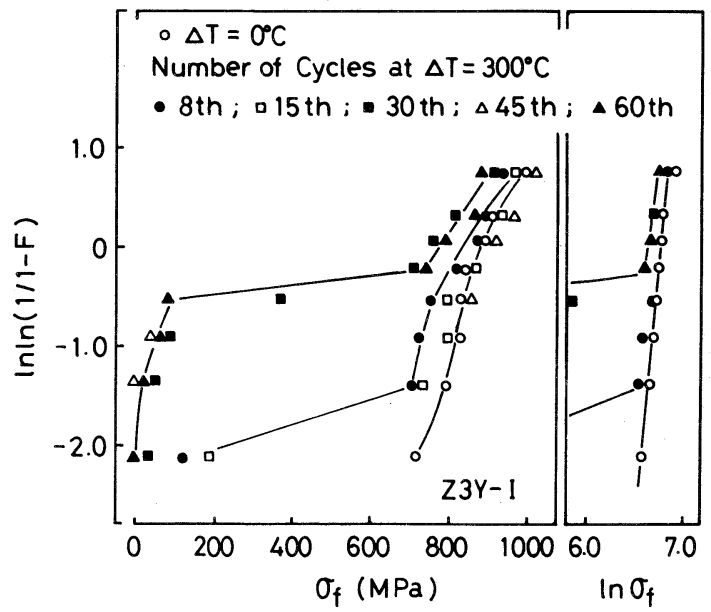

Fig. 4. Retained strength of multiple cycle thermal shocked specimens $(Z 3 \mathrm{Y}-\mathrm{I})$ for $\Delta T=300^{\circ} \mathrm{C}$ shown using the Weibull distribution function and the doubly exponential distribution function.
にあった．最高強度を示す破線 $\mathrm{A}$ は急冷回数が増すにつ れわずかずつではあるが低下する傾向を示した。一方, き裂が入っていないグループの中の最低強度を示す破線 $\mathrm{B}$ は急冷回数が増加しても $715 \mathrm{MPa}$ 程度の一定值を示 した. 図 5 中には平均強度も示しているが， $\Delta T=$ $300^{\circ} \mathrm{C}$ での熱衝撃破壊による強度劣化は平均的に進行す るのでなく，一定の条件にかなったものから順次き裂が 入り強度低下を起こしていくことを反映して標準偏差が 非常に大きくなっており， $\Delta T=350^{\circ} \mathrm{C}$ の場合と同様に 平均強度の変化のみから熱疲労を考察するのは因難で あった。

一方，図 6 に示すように，Z 3 Y-II の残存強度分布 は 5 回の急冷では全体的に低強度側へ移行しているが,

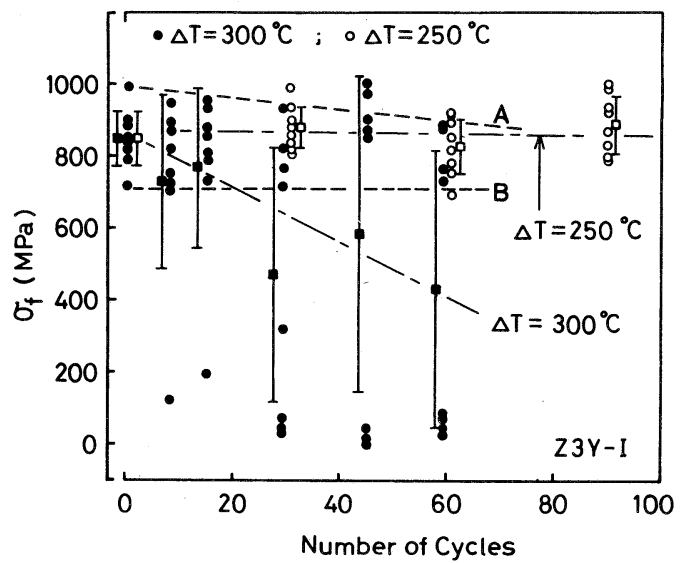

Fig. 5. Relation between retained strength of multiple cycle thermal shocked specimens (Z 3 Y-I) and the number of thermal shock cycles. Marks $\square$ and $\square$ are the average retained strength for $\Delta T=300^{\circ}$ and $250^{\circ} \mathrm{C}$, respectively. Error bars represent \pm 1 standard deviation.

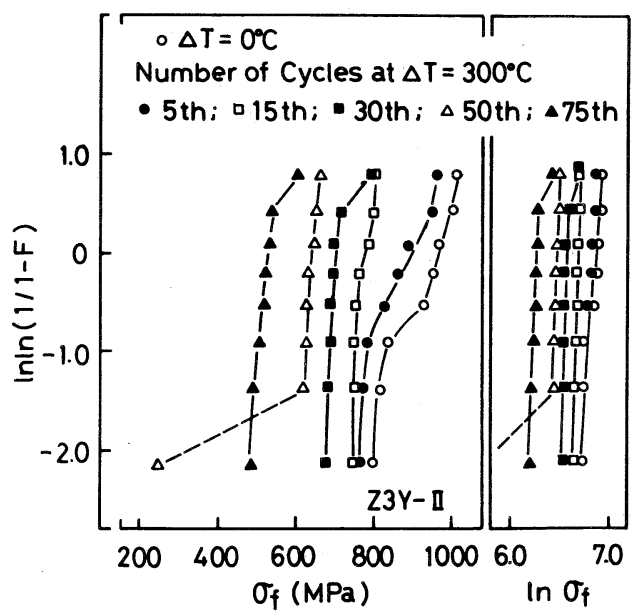

Fig. 6. Retained strength of multiple cycle thermal shocked specimens $\left(Z_{3} \mathrm{Y}-\mathrm{II}\right)$ for $\Delta T=300^{\circ} \mathrm{C}$ shown using the Weibull distribution function and the doubly exponential distribution function. 


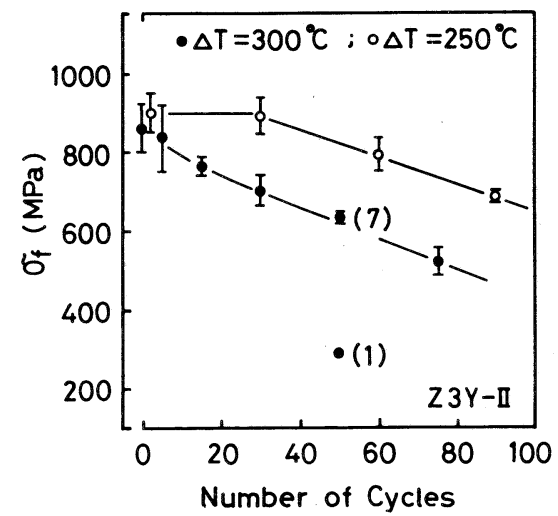

Fig. 7. Variation of average retained strength of $\mathrm{Z} 3 \mathrm{Y}$ II with the number of thermal shock cycles. Error bars are \pm 1 standard deviation. The numbers in parentheses are the number or specimens.

急冷する前 $\left(\Delta T=0^{\circ} \mathrm{C}\right)$ の強度分布と類似していた。 しかし急冷回数が増加すると低強度側に比べて高強度側 の強度低下が相対的に大きくなるため, 15 回の急冷で は高強度側と低強度側の強度差がほとんどなくなり，グ ループ内の強度分布は $3.1 \%$ 以内におさまった. 急冷回 数が 30 回, 50 回, 75 回と増加した場合の強度分布を見 てみると, 1 グループ 8 個の中の 1 個程度の例外を除い て, それぞれの急冷回数でのグループ内の強度差は非常 に小さく, 平均強度での議論が可能である.

$\mathrm{Z} 3 \mathrm{Y}$-II の $\Delta T=300^{\circ} \mathrm{C}$ での平均強度と繰り返し急冷 回数との関係を示したのが図 7 である. 繰り返し急冷回 数が増加するにつれ平均強度は次第に低下し，75回の 急冷では急冷する前の強度の $60 \%$ 程度になった。

\section{( 3 ) $\Delta T=250^{\circ} \mathrm{C}$}

$\Delta T=250^{\circ} \mathrm{C}$ でのZ 3 Y - I の測定結果も図 5 に示し た.急冷を 90 回まで繰り返したが, その強度分布は急 冷する前の強度分布とほとんど同じで強度低下は認めら れなかった.Z 3 Y.II の平均強度の変化は図 7 に示した. 図より明らかなように 30 回までの強度分布は急冷する 前の強度分布とほとんど変わりがなかったが, 30 回以 上の繰り返し急冷で強度低下が始まり, その低下の傾向 は $\Delta T=300^{\circ} \mathrm{C}$ の場合の Z $3 \mathrm{Y}$ - II の低下の傾向とよく 対応していた. 90 回の急冷では急冷する前の強度の $76 \%$ まで低下した.

\section{4. 考 察}

イットリア添加正方晶ジルコニアの臨界温度差 $\Delta T_{\mathrm{c}}$ 以下の急冷温度差での熱衝撃破壊に関係する現象として は slow crack growth (SCG と略す) が関与した疲労 ${ }^{21)}$ と, 熱水と正方晶ジルコニアの反応による劣化 ${ }^{221,23)}$ を挙 げることができる.

温度差 $\Delta T$ の急冷を受けた試料表面に発生する熱応
力 (引っ張り) $\sigma_{\mathrm{t}}$ は

$$
\sigma_{\mathrm{t}}=\frac{\alpha E \Delta T}{1-\nu} \cdot \frac{1}{f(\beta)}
$$

となる.ここで $f(\beta)$ は理想的な急冷からの偏倚を示す パラメーターでビオ係数 $\beta$ の関数である. 試料の寸法 特性を $a$, 熱伝導度を $k$, 熱伝達係数を $h$ とすると, ビオ係数 $\beta$ は次のように表される.

$$
\beta=\frac{a h}{k}
$$

本研究ではヤング率 $E$ を $201.8 \mathrm{GPa}$ ，ポアソン比 0.310 , 熱膨張係数 $\alpha$ を $8.5 \times 10^{-6} 1 /{ }^{\circ} \mathrm{C}$, 熱伝導度 $k$ を $7 \times 10^{-3} \mathrm{cal} / \mathrm{cm} \cdot{ }^{\circ} \mathrm{C} \cdot \mathrm{s}$, 熱伝達係数 $h$ を $0.4 \mathrm{cal} / \mathrm{cm}^{2}$. ${ }^{\circ} \mathrm{C} \cdot \mathrm{s}$ として $\beta$ を算出し, $\beta$ より $f(\beta)$ の推定には Satyamurthy らの研究結果 ${ }^{24)}$ を利用した.

ここでは，まず SCG が強度低下によ゙のような影響を 与えるかを検討することにする。

図 8 は Z 3 Y-I の $\Delta T=300^{\circ} \mathrm{C}$ における SCG での強 度低下現象を説明するために作った模式図である。縦軸 の $F$ は破壊確率で, 横軸には曲げ応力から換算した引っ 張り応力を採用した. $\Delta T=300^{\circ} \mathrm{C}$ の急冷を行った場合 の試料表面に発生する熱応力（引っ張り）を（1）式で 推定し, それを図 8 中の直線 $\mathrm{B}_{1} \mathrm{~B}_{2}$ として示した。推定 された熱応力は $436 \mathrm{MPa}$ で曲げ強度から推定した材料 の最小引っ張り強度 $463 \mathrm{MPa}$ より小さいため 1 ～ 2 回 の急冷では試料は破壊しない. しかし, $436 \mathrm{MPa}$ の熱 応力に相当する急冷温度差 $\Delta T=300^{\circ} \mathrm{C}$ の急冷を繰り返 すと SCGのために材料中の潜在微小き裂が成長する.

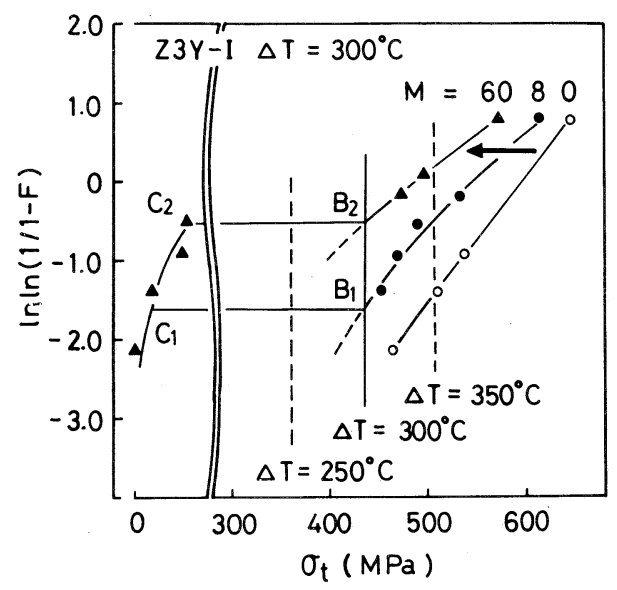

Fig. 8. Relation between failure probability $F$ and fracture tensile strength $\sigma_{\mathrm{t}}$ estimated from the flexural strength of Z3Y.I (schematic diagram). Solid line $\mathrm{B}_{2} \mathrm{~B}_{1}$ corresponds to the thermal stress at $\Delta T=350^{\circ} \mathrm{C}$, and two broken lines correspond to the thermal stresses at $\Delta T=350^{\circ}$ and $250^{\circ} \mathrm{C}$ respectively. $\mathrm{B}_{1}$ and $\mathrm{B}_{2}$ show the initiation points of thermal shock damage for eight and sixty thermal shock cycles, respectively. Solid line $\mathrm{C}_{2} \mathrm{C}_{1}$ is the strength distribution of damaged specimens. $M$ is the number of thermal shock cycles. 
それゆえ，繰り汳し急冷回数が增すと分布曲線全体が矢 印の方向へ移動する.繰り返し急冷回数 $M$ が 8 回の上 きの分布曲線は $\Delta T=300^{\circ} \mathrm{C}$ での熱応力レベルである直 線 $\mathrm{B}_{1} \mathrm{~B}_{2}$ と $\mathrm{B}_{1}$ 点で交差するため, 分布曲線上の $\mathrm{B}_{1}$ 点以 下の強度の試料には巨視的き裂が入り強度低下を起こ し, 曲線 $\mathrm{C}_{1} \mathrm{C}_{2}$ 上の $\mathrm{C}_{1}$ 以下の強度へ之移動する。本研 究の場合, 1 組の試料の数が少ないため低強度側の 1 個 の試料のみにき裂が入り強度低下を起こしている。繰り 返し急冷回数が増えると強度分布曲線は更に低強度側一 移行し, 急冷回数 $M$ が 60 回では $\Delta T=300^{\circ} \mathrm{C}$ での熱応 カレベルである直線 $\mathrm{B}_{1} \mathrm{~B}_{2}$ と $\mathrm{B}_{2}$ 点で交差するため $\mathrm{B}_{2}$ 点以下の強度をもつ材料には巨視的き裂が発生し, その 強度は曲線 $\mathrm{C}_{2} \mathrm{C}_{1}$ まで低下する。

図 5 では $\Delta T=300^{\circ} \mathrm{C}$ での繰り返し急冷後の残存強度 の大部分は破線 $\mathrm{A}$ と破線 $\mathrm{B}$ 間にあることを述べた。一方， 図 8 では急冷回数が増すにつれて Z 3 Y - I の分布曲線 全体が低強度側へ移動することを述べた。すなわち，急 冷回数が増すにつれ一つのグループ内の最大強度もわず かずつではあるが低強度側へ低下していくことになる。

$M=0$ と $M=60$ の最大引っ張り強度差を求めると 72 $\mathrm{MPa}$ となる。これは図 5 の $M=0$ と $M=60$ の最大曲 げ強度差 $111 \mathrm{MPa}$ に相当する，このように繰り返し急 冷回数の增加とともに SCGによりそれぞれのグループ 内の最大強度も低下するため, そ机を反映して図 5 の曲 線 $\mathrm{A}$ は減少傾向を示したものと考えられる。一方, 繰り 返し回数が増えるとともに図 8 中の分布曲線は矢印の方 向，すなわち，低強度側へ移行するが，それぞれの分布 曲線上で $\Delta T=300^{\circ} \mathrm{C}$ での熱応力 $436 \mathrm{MPa}$ より小い 強度の試料にはき裂が入り強度が低下するため, 図 5 の ように巨視的き裂が発生していない試料グループの最低 強度は破線 $\mathrm{B}$ のように繰り返し急冷回数が増えても一定 強度を示すものと推测される。すすなわち, 図 5 中の破線 $\mathrm{B}$ は図 8 中の $\Delta T=300^{\circ} \mathrm{C}$ での熱応力を示す直線 $\mathrm{B}_{1} \mathrm{~B}_{2}$ に対応すると考光られる。

一方，図６に示すようにZ３Y－II の上うな粒径の大 きい試料は繰り返し急冷回数の増加とともに試料全体が 強度低下を起こし, 15 回以上の急冷では一つのグルー プ内の強度分布の幅が非常に小さくなることを述べた。 このようなZ 3 Y-II の繰り返し急冷下での劣化現象は Z 3 Y - I の場合と非常に異なっている. この原因とし て $300^{\circ} \mathrm{C}$ から水中へ急冷する際の熱水上の反応による 試料表面の劣化の問題を挙げることができる22, 23!. 佐藤 亡島田は $83^{\circ} \sim 120^{\circ} \mathrm{C}$ の熱水中に保持した粒径の大きい 正方晶ジルコニア試料表面の正方晶は単斜晶へ相変態を 起こし, 試料表面に微小き裂が発生し, 強度劣化を起こ す上報告している23!

图 9 は $\Delta T=300^{\circ} \mathrm{C}$ の水中急冷を 50 回繰り返した Z 3 Y - II 八染色浸透液を浸透させた後の断面の顕微鏡写

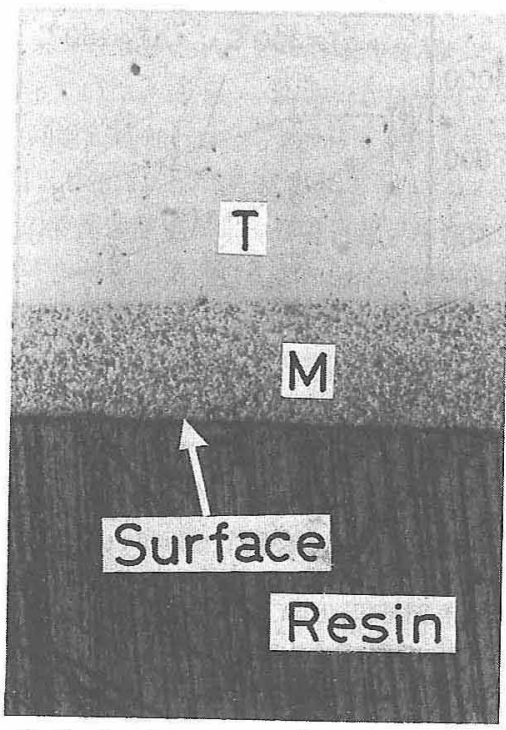

Fig. 9. Optical microscope photograph of the transformed zone in Z $3 \mathrm{Y}$ - II subjected to fifty cycle thermal shock at $\Delta T=300^{\circ} \mathrm{C}$ (colored by dye penetrant). $T$ and $M$ correspond to tetragonal and monoclinic phases, respectively.

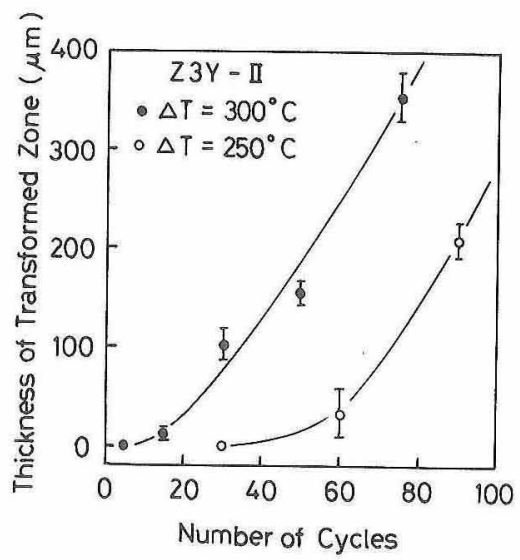

Fig. 10. Relation between the thickness of transformed zone and number of thermal shock cycles for Z 3 Y-II.

真である．表面から約 $150 \mu \mathrm{m}$ の厚さだけ単斜晶へ変態 し微細き裂が生成していることが分かる. 種々の繰り返 し急冷を受けた試料の変態層の厚さを測定し, 繰り返し 急冷回数との関係でプロットしたのが図 10 である。ま た図 7 の強度劣化を図 10 の変態層の厚さで整理すると $\Delta T=300^{\circ}$ 及び $250^{\circ} \mathrm{C}$ の結果が一つの関係で整理でき る.これらのことより Z 3 Y-I の繰り返し急冷による 強度劣化は熱水との反応によって生じた変態層(単斜晶) の厚さの増加のためであると考えられる。このような Z 3 Y-II の強度劣化に Z 3 Y-I で述べたような熱応力が 関与しての SCGによる疲労が関与していないのかどう か検討してみる，既に述べたようにＺ３Ｙ－II の表面は 
熱水との反応により単斜晶へ変態して微細なき裂が発生 するため表面層のヤング率 $E$ は低下する。このような ヤング率 $E$ の小さいぜい化層が発生すると（1）式か ら明らかなように急冷により発生する表面での熱応力 的は小さくなるため, SCG の関与による疲労はほ上ん ビ無視できるものと推測される。

急冷温度差 $\Delta T$ が $350^{\circ} \mathrm{C}$ と高温になると，この急冷 温度差に対応する熱応力（引っ張り）も509 MPa と大 きくなる. 図 8 に示すように急冷する前 $(M=0)$ の分 布曲線中の試料にはこの熱応力より小さいものがあるた め, 1 回目の急冷でも一部の試料にはき裂が発生し，強 度低下を起こす。繰り返し回数の増加とともに分布曲線 は矢印の方向へ，すなわち，低強度側へ移行するため分 布曲線中の試料で $\Delta T=350^{\circ} \mathrm{C}$ の熱応力より小さい強度 をもつ試料の数が増加するためき裂が発生し強度低下を 起こす試料の割合も大きくなり，10回の急冷では大部 分の試料にき裂が入り劣化したものと推測される。Z3 Y-II の場合には $\Delta T=300^{\circ} \mathrm{C}$ の場合（図 6, 図 7）と同 様に熱水との反応による強度劣化の関与も考えられる。

しかし, $\Delta T=350^{\circ} \mathrm{C}$ の場合の熱応力は $\Delta T=300^{\circ} \mathrm{C}$ の 場合に比べ大きくなるため SCG によるき裂の発生が繰 り返し急冷回数 $M$ がそれほよ゙大きくないあいだ（5〜 10 回）に急速に進行してしまうため, 熱水と正方晶ジ ルコニアの反応による劣化の寄与が無視でき, Z 3 Y-I とZ 3 Y-II はほとんど類似した挙動を示したものと考 えられる。

急冷温度差 $\Delta T$ が $250^{\circ} \mathrm{C}$ と低くなると発生する熱応 力 (引っ張り) は $363 \mathrm{MPa}$ と小さいため $\mathrm{SCG}$ の関与 もほとんど無視できるようになり Z 3 Y - I の場合, 90 回の急冷を繰り返してもき裂の発生はなかったが，Z 3 Y-II では正方晶ジルコニアと熱水との反応が進行する ため図 7 のような強度劣化が生じたものと考えられる。

\section{5. 結言}

平均粒径が $0.4 \mu \mathrm{m}(\mathrm{Z} 3 \mathrm{Y}$ - I ) と $1.0 \mu \mathrm{m}(\mathrm{Z} 3 \mathrm{Y}$ - II ) の $3 \mathrm{~mol} \%$ イットリア添加正方晶ジルコニア (Y-TZP) の熱疲労を水中急冷法で測定し，以下のような結論を得 た.

（1）急冷温度差 $\Delta T$ が $350^{\circ} \mathrm{C}$ の場合，Z $3 \mathrm{Y}-\mathrm{I}$ も Z 3 Y-II も 1 回の急冷で半数の試料にき裂が発生し強 度低下を起こしたが，残り半数の試料は急冷する前の強 度と同程度の高い強度を維持していた．高強度側のき裂 が入ってない半数の試料も急冷回数が多くなるとき裂が 発生し，強度劣化する割合が多くなった。10 回の急冷 では大部分の試料にき裂が入ったが，2〜3 個の試料は 急冷する前の強度分布に近い值を維持していた。

（2）急冷温度差 $\Delta T$ が $300^{\circ} \mathrm{C}$ の場合，Z $3 \mathrm{Y}$ - I は 1 回程度の急冷ではき裂の発生が認められなかったが,
繰り返し急冷回数が多くなると熱応力による slow crack growth が関与し, 潜在き裂が成長し，8回の急冷 回数では低強度側の一部の試料に，急冷回数が 60 回に なると半数の試料にき裂が発生し強度劣化を生じた。し かし，高強度側の残りの試料は急冷する前の強度分布と 類似した傾向を示した。一方，Z 3 Y-II の場合，急冷 中に表面の正方晶ジルコニアが熱水と反応し単斜晶へ変 態するため繰り返し回数の増加とともに強度劣化を起こ し，75回急冷では急冷する前の強度の $60 \%$ 程度になっ た.また 15 回以上の急冷では高強度側と低強度側の強 度差が小さくなり $3.1 \%$ 以内におさまった。

（3） $\Delta T=250^{\circ} \mathrm{C}$ の場合，発生する熱応力が小さい ため，Z 3 Y-I は90回の急冷でもき裂の発生が認めら れなかった. 一方, Z 3 Y-II は正方晶ジルコニアと熱 水との反応による正方晶から単斜晶への変態が生じるた め, 繰り返し急冷回数の増加とともに強度劣化を生じ, 90 回急冷では急冷する前の強度の $76 \%$ まで低下した。

（4）繰り返し急冷を受けたZ 3 Y-II の正方晶から 単斜晶への変態層の厚さは, $\Delta T=300^{\circ} \mathrm{C}$ の場合, 急冷 回数 $M$ が 30 回で $103 \mu \mathrm{m}, 50$ 回で $155 \mu \mathrm{m}, 75$ 回で $356 \mu \mathrm{m}, \Delta T=250^{\circ} \mathrm{C}$ の場合, 60 回で $36 \mu \mathrm{m}, 90$ 回で $211 \mu \mathrm{m}$ であった。

\section{文献}

1) R.W. Davidge and Tappin, Trans. Brit. Ceram. Soc., 66, 405-22 (1967).

2) D.P.H. Hasselman, J. Am. Ceram. Soc., 53, 490-95 (1970).

3) T. K. Gupta, J. Am. Ceram. Soc., 55, 249-53 (1972).

4) J.A. Coppolar and R. C. Bradt, J. Am. Ceram. Soc., 56, 214-18 (1973).

5) D.P.H. Hasselman, J. Am. Ceram. Soc., 52, 600-04 (1969).

6) M. Ashizuka, T. E. Easler and R. C. Bradt, J. Am. Ceram. Soc., 66, 542-50 (1983).

7) R. C. Garvie and P. S. Nicholson, J. Am. Ceram. Soc., 55, $152-57$ (1972)

8) N. Claussen and D. P.H. Hasselman, "Thermal Stress in Severe Environment”, Ed. by D. P. H. Hasselman and R. A. Heller, Plenum Press, New York (1980) p. 381-95.

9) P.F. Becker, J. Am. Ceram.Soc., 64, 37-39 (1981).

10）正木孝樹，小林啓佑，昭和 56 年效業協会年会講演予稿集， p. 4.

11）芦塚正博，木村泰之，藤井秀樹，阿辺浩市，淮田吉孝， 䇺協, 94, 577-82 (1986)

12) D.P. H. Hasselman, E.P. Chen, C. L. Ammann, J.E. Doherty and C. G. Nessler, J. Am. Ceram. Soc., 58, 513-16 (1975).

13) D. P. H. Hasselman, R. Badaliance, K. R. Mckinnery and C. H. Kim, J. Mater. Sci. 11, 458-64 (1976).

14) D. P. H. Hasselman, E. P. Chen and P. A. Urick, Am. Ceram. Soc. Bull., 57, 190-92 (1978).

15) C. L. Ammann, J.E. Doherty and C.G. Nessler, Mater. Sci. Eng., 22, 15-22 (1976).

16) N. Kamiya and O. Kamigaito, J. Mater. Sci. Letters, 13, 212-14 (1978).

17) N. Kamiya and O. Kamigaito, J. Mater. Sci., 14, 
573-82 (1979).

18) J.P. Singh, K. Niihara and D. P. H. Hasselman, J. Mater. Sci., 16, 2789-97 (1981).

19) J. Lamon, J. Mater. Sci., 16, 2119-29 (1981).

20) D. Lewis and R. W. Rice, Ceram. Eng. Sci. Proc., 2, 712-18 (19881).

21）芦塚正博, 清原秀樹, 石田英一, 桑原 誠, 窪田吉孝, 月舘隆明，窯協，94，432-39 (1986).
22) K. Nakajima, K. Kobayashi and Y. Murata, "Advances in Ceramics, Vol. 12, Science and Technology of Zirconia II", Ed. by N. Claussen, M. Rühler and A.H. Heuer, Am. Ceram. Soc. (1984) p. 399-407.

23) T. Sato and M. Shimada, J. Am. Ceram. Soc., 68, 356-59 (1985).

24) K. Satyamurthy, J. P. Singh, D. P. H. Hasselman and M. P. Kamat, J. Am. Ceram. Soc., 63, 694-98 (1980). 